Tanjungpura Law Journal, Vol. 4, Issue 1, January 2020: 82 - 94

ISSN Print: 2541-0482 | ISSN Online: 2541-0490

Open Access at: http://jurnal.untan.ac.id/index.php/tlj

Article Info

Submitted: 2 November 2019 | Reviewed: 18 November 2019 | Accepted: 5 Desember 2019

\title{
PENGARUH YURISPRUDENSI TERHADAP PRINSIP KEMERDEKAAN HAKIM
}

\author{
Favian Partogi Alexander Sianipar ${ }^{1}$
}

\begin{abstract}
In the legal system in Indonesia, a jurisprudence is often used in the context of legal discovery. Although theoretically, the Judge is not bound by Jurisprudence, on the other hand, it creates a firm intention for Judges to follow higher court decisions. This raises a contradiction regarding the position of Jurisprudence in the legal system adopted in Indonesia. The contradiction came from legal scholars in particular Judges who did not approve of the use of Jurisprudence in their decisions because it violated the independence of Judges who had been regulated in Article 24 of the 1945 Constitution of the Republic of Indonesia and guidelines for the enforcement of a code of ethics and a code of conduct for judges. Based on the discussion above, in this article, the writer is interested in exploring whether the application of jurisprudence can affect the independence of judges. This article concludes that when the Supreme Court judges a court decision with a permanent legal force as a jurisprudence, it is changed into positive law. Then other judges can use jurisprudence as a basis for consideration in their decisions. This certainly does not damage the independence of the Judges listed in the code of ethics in deciding a case.
\end{abstract}

Keywords: court; jurisprudence; judge independence

\begin{abstract}
Abstrak
Dalam sistem Hukum di Indonesia masih sering digunakan suatu Yurisprudensi dalam rangka penemuan hukum. Sekalipun secara teoritis memang Hakim tidak terikat dengan Yurisprudensi namun disisi lain menciptakan intensi yang kuat bagi para Hakim untuk mengikuti putusanputusan pengadilan yang lebih tinggi. Hal ini menimbulkan suatu pertentangan mengenai kedudukanYurisprudensi dalam sistem hukum yang dianut di Indonesia. Pertentangan tersebut berasal dari sarjana hukum pada khususnya Hakim yang tidak menyetujui digunakan Yurisprudensi dalam putusannya karena melanggar suatu kemandirian Hakim yang telah diatur dalam Pasal 24 Undang-Undang Dasar Negara Republik Indonesia Tahun 1945 serta panduan penegakan kode etik dan pedoman perilaku Hakim. Bertitik tolak dari pembahasan tersebut di atas, dalam artikel ini penulis tertarik untuk menggali apakah berlakunya yurisprudensi dapat mempengaruhi kemerdekaan hakim. Artikel ini menyimpulkan bahwa Ketika Suatu putusan Pengadilan yang berkekuatan hukum tetap tersebut di nilai oleh Mahkamah Agung sebagai sebuah Yurisprudensi, maka sifatnya berubah menjadi hukum positif. Maka Hakim lain dapat mempergunakan yurisprudensi tersebut sebagai dasar pertimbangan dalam putusannya. Hal tersebut tentu tidak menciderai kemandirian Hakim yang tercantum dalam kode etik dalam memutuskan suatu perkara.
\end{abstract}

Kata Kunci: independensi hakim; pengadilan; yurisprudensi

\footnotetext{
${ }^{1}$ Pegawai Negeri Sipil Mahkamah Agung, email: favian.alexander@gmail.com
} 


\section{Pendahuluan}

Di dalam mewujudkan keadilan, tidak jarang Hakim dalam menerima, memeriksa dan mengadili suatu perkara menemukan kondisi atau peristiwa yang belum diatur dalam peraturan perundang-undangan. Kondisi seperti ini sering disebut dengan kekosongan hukum. Hakim sebagai pejabat negara yang diberikan mandat untuk menjalankan kekuasaan Kehakiman harus menemukan hukum sehingga tercipta sesuatu keadilan di masyarakat sekalipun tidak ada aturan sebelumnya. Sehubungan dengan hal ini telah diatur di dalam Pasal 10 ayat (1) Undangundang Nomor 48 Tahun 2009 yakni sebagai berikut: "Pengadilan tidak boleh menolak untuk memeriksa, mengadili, dan memutuskan suatu perkara yang diajukan dengan dalil bahwa hukum tidak ada atau kurang jelas, melainkan wajib untuk memeriksa dan mengadilinya".

Dalam hal memeriksa, mengadili dan memutuskan perkara tersebut diatas, Hakim harus melakukan penemuan hukum berdasarkan pasal 5 ayat (1) Undang-Undang Nomor 48 Tahun 2009 tentang Kekuasaan Kehakiman, yaitu "Hakim dan Hakim Konstitusi wajib menggali, mengikuti, memahami nilai-nilai hukum dan rasa keadilan yang hidup dalam masyarakat." Ketentuan ini, mengandung makna bahwa Hakim dilarang menolak suatu perkara yang dihadapkan kepadanya dengan alasan hukumnya tidak ada atau kurang jelas. Dalam sistem penegakan hukum di Indonesia, hakim adalah salah satu aparat penegak hukum. Sebagai pelaku utama badan peradilan, maka posisi dan peran hakim sebagai aparat penegak hukum di semua tingkat pengadilan menjadi sangat penting, terlebih dengan segala kewenangan yang dimilikinya. $^{2}$

Dalam hal hukumnya tidak ada atau tidak jelas, Hakim wajib menggali nilai-nilai hukum dan rasa keadilan yang terkandung dalam kehidupan masyarakat yang bersangkutan. Sehingga Hakim dituntut untuk menciptakan suatu putusan yang pertimbangannya berdasarkan nilai-nilai yang berkembang dimasyarakat. Putusan Hakim semacam ini dapat menjadi preseden dikalangan Hakim lainnya apabila menemukan kondisi seperti demikian. Konsep ini lebih sering dikenal dengan Yurisprudensi.

Yurisprudensi adalah putusanputusan Hakim atau pengadilan yang tetap dan dibenarkan oleh MA sebagai

\footnotetext{
2 Zaki Ulya, 2016. "Pembatalan Kewenangan Komisi Yudisial Dalam Rekrutmen Hakim Dikaitkan Dengan Konsep Independensi Hakim (Studi Putusan Mahkamah Konstitusi Nomor 43/Puu-Xiii/2015)", Mimbar Hukum, 28 (3): 482-496.
} 
pengadilan kasasi, atau putusanputusan MA sendiri yang tetap. ${ }^{3}$ Putusan tersebut kemudian dijadikan dasar untuk menyelesaikan kasuskasus serupa dikemudian hari. Biasanya hal ini akan terjadi jika telah terjadi beberapa kali kasus yang serupa dan untuk kasus-kasus itu Hakim selalu memberikan keputusan dengan cara yang kurang lebih sama. Perulangan itu menimbulkan rasa keharusan untuk memutuskan dengan cara yang sama setiap kali kasus serupa terjadi. Dengan demikian terbentuk hukum melalui keputusan Hakim. ${ }^{4}$

Yurisprudensi memiliki fungsi yang penting dalam perkembangan ilmu hukum. Yurisprudensi merupakan produk hukum dari lembaga yudikatif. ${ }^{5}$ Yurisprudensi adalah salah satu bentuk partisipasi kekuasaan yudikatif dalam proses pembentukan hukum dalam arti luas. Seperti pembahasan diatas, bahwa Yurisprudensi merupakan sarana pengisi suatu kekosongan hukum dalam hal Undang-Undang tidak mampu mengikuti perkembangan nilai yang hidup di Masyarakat. Hal ini sesuai dengan pendapat dari Oetojo Oesman,

\footnotetext{
${ }^{3}$ Badan Pembinaan Hukum Nasional (BPHN), 1992, Peningkatan Yurisprudensi Sebagai Sumber Hukum, Penelitian Hukum, Jakarta: Badan Pembinaan Hukum Nasional, hlm. 8-12. 4 Johannes Ibrahim dan Lindawaty Sewu, 2007, Hukum Hakim, Judge Made Law, hIm 64.

${ }^{5}$ Puslitbang Hukum dan Peradilan Badan Litbang Diklat Kumdil MA RI, 2010, Kedudukan dan Relevansi Yurisprudensi Untuk Mengurangi Disparitas Putusan Pengadilan, Laporan Penelitian, Jakarta: Penerbit Balitbang
}

Mantan Menteri Kehakiman dalam seminar hukum nasional tahun $1994{ }^{6}$

Selain terkait dengan pembentukan hukum, Yurisprudensi terkait juga dengan akuntabilitas dan pengawasan Hakim. Yurisprudensi dapat menunjang pembaharuan dan pembinaan hukum. ${ }^{7}$ Semakin konsisten para Hakim dalam memutus perkara yang sama maka akan semakin baik sistem peradilan secara keseluruhan, dimana dengan yurisprudensi dalam fungsinya sebagai panduan tadi, Hakim dapat menekan angka disparitas. Dengan kekonsistenan dalam memandang suatu fakta hukum, maka akan mudah melihat adanya berbagai masalah dari para Hakim dalam mengadili suatu perkara. Hal ini terkait fungsi Mahkamah Agung (MA) salah satunya adalah pengawasan terhadap Hakim-Hakim.

Secara teori, terdapat perbedaan antara Yurisprudensi di dalam sistem hukum civil law dan sistem common law. Yurisprudensi dalam sistem civil law bersifat lebih persuasif atau fleksibel. Artinya Yurisprudensi tersebut tidak mengikat untuk digunakan, sedangkan Yurisprudensi

Pendidikan dan Pelatihan hukum dan Peradilan MA RI, hIm. 103.

${ }^{6}$ Sebastiaan Pompe, 2012, Runtuhnya Institusi Mahkamah Agung, Jakarta: Lembaga Kajian dan Advokasi untuk Independensi Peradilan, hlm.. 601.

${ }^{7}$ Puslitbang Hukum dan Peradilan Badan Litbang Diklat Kumdil MA RI, loc.cit. 
dalam sistem Common Law bersifat mengikat. Walaupun dalam prakteknya seringkali Yurisprudensi didalam sistem civil law tidak kalah kuatnya dengan Yurisprudensi dalam sistem common law. ${ }^{8}$ Sebagai contoh Yurisprudensi yang secara konsisten dipakai oleh MA sebagai rujukan dasar hukum adalah tentang kasasi atas putusan bebas yang berasal dari Putusan Mahkamah Agung No. 275 K/Pid/1983 atas nama Raden Sonson Natalegawa. Dimana melalui putusan ini muncullah istilah bebas murni dan bebas tidak murni, yang kemudian putusan bebas tidak murni dapat diajukan kasasi oleh penuntut umum. Berdasarkan hal tersebut hasil penelitian LeIP menyebutkan bahwa pada kurun waktu 2009-2011 terdapat sekitar 130 daftar perkara yang mengikuti Yurisprudensi tersebut. ${ }^{9}$

Berdasarkan hal tersebut diatas nampaklah bahwa dalam sistem Hukum di Indonesia masih sering digunakan suatu Yurisprudensi dalam rangka penemuan hukum atau adanya suatu kekosongan hukum. Hal ini didukung pula dengan pendapat Sebastian Pompe yang tercantum dalam varia peradilan yang menyatakan bahwa "keinginan dari para Hakim sangat kuat mengikuti Yurisprudensi. Sekalipun secara teoritis memang Hakim tidak

\footnotetext{
${ }^{8}$ Oetojo Oesman, op.cit., hlm. 605.

9 Sabrina Asril, LelP: Ada 130 Kasus yang Diterima Kasasinya oleh MA, https://nasional.kompas.com/read/
}

terikat dengan Yurisprudensi namun disisi lain menciptakan intensi yang kuat bagi para Hakim untuk mengikuti putusan-putusan pengadilan yang lebih tinggi”. ${ }^{10}$

Hal ini menimbulkan suatu pertentangan mengenai kedudukan Yurisprudensi dalam sistem hukum yang dianut di Indonesia. Pertentangan tersebut berasal dari sarjana hukum pada khususnya Hakim yang tidak menyetujui dipakainya Yurisprudensi dalam putusannya karena melanggar suatu kemandirian Hakim yang telah diatur dalam Pasal 24 Undang-Undang Dasar Negara Republik Indonesia Tahun 1945 serta panduan penegakan kode etik dan pedoman perilaku Hakim. Bertitik tolak dari pembahasan tersebut di atas, dalam artikel ini penulis tertarik untuk menggali apakah berlakunya yurisprudensi dapat mempengaruhi kemerdekaan hakim.

\section{Metode}

Artikel ini mengguanakan penelitian hukum normatif-yuridis, serta dapat digolongkan kedalam tipe peneloitian deskiptif. Menurut Soerjono Soekanto, Sri Mamudji, dan Soetandyo Wignjosoebroto, bahwa yang dimaksud dengan penelitian hukum normatif adalah penelitian hukum doktrinal yang

2015/02/22/17174431/read-adverd.html, diakses pada tanggal 14 Oktober 2019.

${ }_{10}$ Oetojo Oesman, op.cit., hlm. 608. 
menggunakan konsep-konsep, asasasas dan norma hukum sebagai acuan pokok dalam melakukan penelitian hukum terhadap asas-asas hukum, taraf sinkronisasi hukum, sistematik hukum, perbandingan hukum, dan sejarah hukum. ${ }^{11}$ Dalam tataran yang lebih luas, metode penelitian yang digunakan dalam hal ini dapat pula dikategorikan kedalam tipe penelitian "deskriptifanalitif".

\section{Analisis dan Pembahasan}

Pada awal pembahasan ini, penulis akan memfokuskan pembahasan mengenai pengertian sumber hukum. Sumber hukum merujuk kepada pengertian tempat dari asal muasal suatu nilai atau norma tertentu berasal, sedangkan dasar hukum ataupun landasan hukum, merupakan norma hukum yang mendasari suatu tindakan atau perbuatan hukum tertentu sehingga dapat dianggap sah, atau dapat dibenarkan secara hukum. Sumber hukum dapat dibedakan ke dalam dua pengertian dalam arti formal atau formele zin (sources of law in its formal sense) atau in materiele zin (source of law in material sense). ${ }^{12}$ Sumber hukum dalam arti formal dapat didefinisikan sebagai tempat formal dalam bentuk tertulis dari mana suatu kaidah hukum diambil, sedangkan

11 Soerjono Soekanto dan Sri Mamudji, Penelitian Hukum Normatif, 2001, Suatu Tinjauan Singkat, Jakarta: Rajawali Pers, hlm.1314. sumber hukum dalam arti materil adalah tempat dari mana norma itu berasal, baik dari secara umum, sumber hukum formil dibagi menjadi arti tertulis maupun tidak tertulis. ${ }^{13}$ Secara umum, sumber hukum formil dibagi menjadi lima yaitu: Undang-Undang, Kebiasaaan, Yurisprudensi, Traktat dan Doktrin.

Ada beberapa pendapat ahli yang mempertentangkan apakah sebuah Yurisprudensi sudah tepat dimasukkan sebagai sumber hukum atau tidak. Salah satu ahli yang menolak Yurisprudensi sebagai sumber hukum adalah Van Apeldoorn, yang menyatakan sebagai berikut: "Apabila suatu ketentuan dalam keputusan keputusan Hakim terus menerus diikuti dan dengan begitu rupanya telah menjadi bagian dari keinsyafan hukum umum, jika dengan kata-kata lain, tentang suatu soal hukum tertentu telah tercipta yurisprudensi tetap. Maka ketentuan itu menjadi hukum, tidak berdasarkan keputusan Hakim, tapi berdasarkan kebiasaan, yaitu berdasarkan keinsyafan hukum umum, yang kentara dari tingkah laku tetap para Hakim." Berbanding terbalik dengan Van Apeldoorn, Bellfroid dan E.Utrecht sepakat bahwa Yurisprudensi merupakan suatu sumber hukum, dimana Bellfroid berkata demikian: "Saya tidak sependapat dengan

\footnotetext{
12 Jimly Asshidiqie, 2014, Pengantar Ilmu Hukum Tata Negara, Jakarta: Raja Grafindo Persada, hlm 121.

13 lbid.
} 
Apeldoorn. Penggunaan Arrest Hoge Raad oleh Hakim bawahan disebabkan karena terdesak dari atas (takut dikasasi), jadi bukan karena kebiasaan. Seorang Hakim tidak terikat kepada putusan Hakim lain. Apabila putusan Hakim senantiasa dijadikan dasar oleh Hakim lain dalam kasus-kasus yang sama, maka lahir hukum yang berlaku umum yang disebut yurisprudensi. Putusan Hakim pertama yang dijadikan dasar putusan Hakim selanjutnya merupakan sumber hukum dalam arti formil." Lalu E.Utrecht juga berpendapat demikian: "Putusan Hakim yang memuat peraturan tersendiri, kemudian dijadikan pedoman oleh Hakim lain, maka putusan Hakim pertama menjadi sumber hukum bagi peradilan hukum yang termuat dalam putusan semacam itu disebut hukum yurisprudensi."

Melihat berbagai pertentangan diatas, penulis sepakat dengan pendapat Bellfroid dan Utrecht yang pada pokoknya menyatakan Yurisprudensi merupakan suatu sumber hukum. Harus disadari betul bahwa Hakim memiliki suatu peran dalam mengkonritkan suatu Undang-Undang melalui putusannya. Melalui putusan Hakim suatu peraturan yang semula abstrak menjadi konkrit, suatu pertimbangan Hakim yang dituangkan dalam putusan akan hilang sifatnya

14 Maria Farida, 2011, IImu Perundangundangan 1, cet. ke- 5, Yogyakarta: Penerbit Kanisius, 2011. hlm. 41. sebagai sebuah pertimbangan dan beralih menjadi hukum positif apabila putusannya telah berkekuatan hukum tetap. Ditambah lagi dalam posisi terjadinya kekosongan hukum, Hakim sebagai pemberi keadilan harus mampu menciptakan hukum, karena dipundak seorang Hakim dilekatkan asas Ius Curia Novit atau dengan kata lain, Hakim dianggap mengetahui seluruh hukum. Sehingga dalam kondisi kekosongan hukum, maka Hakim dituntut dapat membuat suatu hukum positif melalui putusannya. Tentunya hal ini dapat menjadi suatu sumber hukum yang dapat dipakai oleh Hakim lain dalam memutus perkara yang serupa namun belum ada dasar hukum dari peraturan perundang-undangan.

Dalam melihat letak Yurisprudensi dalam susunan peraturan perundang-undangan, maka Hans Kelsen dalam teorinya yang menyatakan bahwa peraturan perundang-undangan itu berjenjangjenjang dan berlapis-lapis dalam suatu hierarki. 14 Semakin ke bawah lapisannya, maka norma tersebut semakin individual dan semakin konkrit. Menurut Hans Kelsen, Undang-Undang dan kebiasaan adalah produk setengah jadi yang diselesaikan hanya melalui putusan pengadilan dan eksekusinya. Proses dimana hukum secara konstan 
memperbaharui diri dari umum dan abstrak menuju individual dan konkrit adalah suatu proses peningkatan menuju individualisasi dan konkritisasi. ${ }^{15}$ Apabila kita melihat suat putusan Hakim baik pidana maupun perdata, maka akan tampak sifatnya yang konkrit dan individual, seperti yang kita bahas diatas, bahwa putusan Hakim membuat suatu peraturan yang semula abstrak menjadi konkrit dan sifatnya individual karena hanya mengikat pihak yang ada dalam perkara tersebut. Sehingga dapat disimpulkan bahwa putusan pengadilan merupakan norma hukum yang sifatnya individual dan konkrit yang dapat langsung dieksekusikan. Karena sifatnya yang indvidual dan konkrit, jika dihubungkan dengan teori ini maka jelas bahwa yurisprudensi merupakan sumber hukum yang berasal dari undang-undang sehingga mengandung norma undang-undang.

Sehubungan dengan hal di atas, adapula yang mengartikan bahwa yurisprudensi bukanlah sebuah keputusan-keputusan Hakim, hal tersebut diungkapkan oleh Mahadi yang mengartikan bahwa yurisprudensi bukan merupakan keputusankeputusan Hakim dan bukan pula rentetan keputusan, melainkan hukum yang terbentuk dari keputusan-

15 Hans Kelsen, 2006, Teori Hans Kelsen Tentang Hukum, Jakarta: Konstitusi Press, hlm. 120.

16 Miftakhul Huda, Yurisprudensi, Majalah Konstitusi Edisi April 2010, hlm 86. keputusan Hakim. ${ }^{16}$ Hukum yang timbul ini akan menjadi hukum positif dimana asas atau kaidahnya menjadi bersifat umum dan dapat dipergunakan sebagai dasar pertimbangan hukum bagi siapa saja. ${ }^{17}$

Oleh karena itu akan timbul pertanyaan putusan Hakim yang bagaimanakah yang dapat dijadikan yurisprudensi sehingga menjadi sumber hukum dikemudian hari, untuk menjawab persoalan ini, Mahkamah Agung melalui surat edaran Mahkamah Agung No. 2 tahun 1972 tentang pengumpulan Yurisprudensi menjelaskan bahwa demi terwujudnya kesatuan hukum maka hanya MA satusatunya lembaga konstitusional yang bertanggung-jawab mengumpulkan yurisprudensi yang harus diikuti oleh Hakim dalam mengadili perkara. Surat Edaran tentang pengumpulan yurisprudensi tersebut sampai saat ini belum pernah dicabut oleh MA dan masih tercantum dalam Himpunan SEMA dan Perma Tahun 1951-2007 yang diterbitkan oleh MA pada tahun 2007, dengan demikian masih berlaku dan menjadi pedoman dalam pengumpulan, penerbitan dan publikasi yurisprudensi. Hal ini mengartikan bahwa wewenang dan tanggung jawab konstitusional untuk mengumpulkan

17 Bagir Manan. 2004, Hukum Positif Indonesia, Satu Kajian Teoritik, Yogyakarta: FH UII Press, hlm 33-34. 
yurisprudensi hanya ada pada MA, institusi di luar MA baik Pemerintah maupun swasta tidak mempunyai wewenang. ${ }^{18}$

\section{Berdasarkan pembahasan}

pembahasan diatas, penulis mengambil kesimpulan bahwa yurisprudensi merupakan suatu hukum positif yang berasal dari keputusan-keputusan Hakim dimana asasnnya bersifat umum sehingga dapat digunakan sebagai dasar pertimbangan hukum bagi siapa saja.

Selanjutnya penulis akan membahas mengenai kemandirian Hakim pada umumnya. Kemandirian Hakim yang berkembang saat ini bermaksud untuk memberikan kemandirian bagi Hakim untuk menjalani tugas yudikatifnya tanpa ada tekanan atau intervensi dari pihak lain. Artinya seorang Hakim harus diberikan ruang yang bebas dalam membuat putusan, sehingga putusan itu dapat mencapai nilai-nilai keadilan. Jika menarik panjang sebuah sejarah kemandirian badan peradilan, maka kita akan dihadapkan mengenai teori pemisahan kekuasaan negara oleh Montesquieu. Teori pemisahan kekuasaan tersebut terbagi atas tiga yaitu eksekutif, legislatif dan yudikatif. Montesquieu berpandangan bahwa jika kekuasaan untuk mengadili tidak

18 Teguh Satya Bhakti, 2017, Pembangunan Hukum Administrasi Negara Melalui PutusanPutusan Peradilan Tata Usaha Negara, Jakarta: dipisahkan dari kekuasaan eksekutif, hal tersebut akan menyebabkan tidak adanya kebebasan dalam masyarakat. Kekuasaan akan sewenang-wenang terhadap kebebasan dan kehidupan rakyat, jika kekuasaan mengadili dan kekuasaan legislatif tidak dipisah.

Pada pokoknya teori pemisahan ini membagi kewenangan lembaga negara sehingga tercipta perbedaan fungsi diantara lembaga negara tersebut. Kewenangan tersebut tidak dapat dicampuri oleh kekuasaan lainnya. Salah satu contoh kekuasaan yang harus dipisahkan dari kekuasaan lainnya adalah kekuasaan Kehakiman. $\mathrm{Di}$ Indonesia, konsep kekuasaan Kehakiman sendiri telah dituangkan dalam pasal 24 ayat (1) Perubahan Ketiga Undang-Undang Dasar Negara Republik Indonesia Tahun 1945 yang menyebutkan bahwa "Kekuasaan Kehakiman merupakan kekuasaan yang merdeka untuk menyelenggarakan peradilan guna menegakkan hukum dan keadilan." Selain dalam UndangUndang Dasar 1945, konsep kekuasaan Kehakiman yang merdeka juga diatur dalam Undang-Undang No. 14 Tahun 1985 tentang Mahkamah Agung. Sebagai sebuah undang-undang organik. Pasal 2 Undang-Undang Mahkamah Agung tersebut mengatur bahwa Mahkamah Agung adalah

Puslitbang Hukum dan Peradilan Badan Litbang Diklat Kumdil Mahkamah Agung Republik Indonesia, hlm. 104. 
pengadilan negara tertinggi dari semua lingkungan peradilan, yang dalam melaksanakan tugasnya terlepas dari pengaruh pemerintah dan pengaruhpengaruh lain. Konsep pemisahan kekuasaan ini selanjutnya diaplikasikan secara konkrit untuk melindungi Hakim dalam menjalankan tugas dan fungsi yudikatifnya. Hal tersebut dituangkan dalam pasal 3 ayat (1) Undang- Undang nomor 48 Tahun 2009 tentang kekuasaan Kehakiman yang menyebutkan bahwa "dalam menjalankan tugas dan fungsinya, Hakim dan Hakim konstitusi wajib menjaga kemandirian peradilan". Terkait dengan hal ini, Luhut M. P. Pangaribuan membagi kekuasaan Kehakiman menjadi dua bentuk, yang pertama ialah kemadirian Hakim ketika mengadili perkara dan yang kedua, ialah lembaga Kehakiman ketika berhadaphadapan dengan kekuasaan legislatif dan ekskutif sekaligus. ${ }^{19}$

Selanjutnya, Bagir Manan membagi konsep kemandirian dan kekuasaan Kehakiman sebagai berikut:

1. Kemandirian secara lembaga.

$\begin{array}{lrr}\text { Maksudnya adalah } \begin{array}{r}\text { secara } \\ \text { kelembagaan }\end{array} & \text { kekuasaan } \\ \text { Kehakiman tidak merupakan } & \text { mabordinat dari lembaga negara }\end{array}$

19 Luhut M. P. Pangaribuan, 2009, Lay Judges \& Hakim Ad Hoc Suatu Studi Teoritis Mengenai Sistem Peradilan Pidana Indonesia, Jakarta: Kerjasama Program Pasca Sarjana Fakultas Hukum Universitas Indonesia dengan Penerbit Papas Sinar Sinanti: Jakarta, hlm. 184. tertentu sedangkan prinsip yang digunakan adalah pemisahan kekuasaan.

2. Kemandirian secara individual Hakim. Dimana Hakim mempunyai otoritas penuh dalam memutuskan suatu perkara, termasuk dalam memutuskan suatu perkara, termasuk dalam menemukan dan menerapkan hukum. Hakim harus diberi kemerdekaan dalam mengambil putusan yang terbaik dan sesuai dengan rasa keadilan masyarakat. Oleh karenanya code of conduct Hakim menjadi sangat diperlukan dan harus ada lembaga yang mengawasi ditaatinya code of conduct tersebut.

3. Kemandirian dalam proses peradilan. Maksudnya adalah proses peradilan harus steril dari segala intervensi eksternal.

Secara lebih kongkret, kebebasan hakim memiliki empat pengertian, yakni:20

1. Tidak terpengaruh oleh pihak-pihak berperkara baik pihak materiil maupun pihak formil

2. Tidak terpengaruh oleh tekanan, paksaan direktiva atau rekomendasi pihak ekstra yudisial dari siapapun dan dari badan apapun

20 Oly Viana Agustine. 2018. "Keberlakuan Yurisprudensi pada Kewenangan Pengujian Undang-Undang dalam Putusan Mahkamah Konstitusi”, Jurnal Konstitusi, 15 (3): 642-665. 
3. Bebas dan berani berinisiatif dan berimprovisasi dalam tugas pemeriksaan

4. Kebebasan yang bertanggung jawab kepada Tuhan Yang Maha Esa, negara dan bangsa, masyarakat, nama baik korp dan diri sendiri

Melalui pengertian pengertian tersebut, dapat ditarik kesimpulan bahwa konsep pemisahan kekuasaan Kehakiman tersebut ditujukan untuk melindungi lembaga kekuasaan Kehakiman yang dalam hal ini Mahkamah Agung maupun Hakim yang berada pada badan peradilan di bawah Mahkamah Agung agar terbebas dari intervensi atau tekanan pihak eksekutif maupun legislatif. Jika kita melihat pendapat Bagir Manan diatas, beliau menjelaskan, dengan kemandirian Hakim, membuat Hakim menjadi objektif dalam memutus suatu perkara maupun menerapkan hukum.

Pada dasarnya Hakim dituntut untuk mandiri dalam menjalankan tugas dan fungsi yudikatifnya, hal ini termasuk pula dalam pembuatan putusan, Hakim dituntut harus objektif dan harus mandiri. Mandiri disini penulis artikan bahwa dalam memutuskan suatu perkara, Hakim harus menuangkan pikiran dan pendapatnya sendiri terhadap kasus tersebut didalam putusannya. Hakim tidak dapat di intervensi atau dipengaruhi oleh pihak lain termasuk pendapat rekan-rekan Hakim lain atau Ketua Pengadilan sekalipun dalam hal pembuatan putusan. Apabila kita merujuk kepada pasal 4 huruf (d) peraturan bersama Ketua Mahkamah Agung Republik Indonesia dan Ketua Komisi Yudisial Republik Indonesia nomor 02/PB/MA/IX/2012 atau 02/PB/P.KY/09/2012 Tentang Panduan Penegakan Kode Etik Dan Pedoman Perilaku Hakim menyebutkan bahwa seorang Hakim wajib bersikap mandiri. Adapun yang dimaksud dengan bersikap mandiri diatur dalam pasal 8 ayat (1) peraturan ini yang menyebutkan "Berperilaku mandiri bermakna mampu bertindak sendiri tanpa bantuan pihak lain, bebas dari campur tangan siapapun dan bebas dari pengaruh apapun. Sikap mandiri mendorong terbentuknya perilaku Hakim yang tangguh, berpegang teguh pada prinsip dan keyakinan atas kebenaran sesuai tuntutan moral dan ketentuan hukum yang berlaku". Kewajiban tersebut dijelaskan lebih lanjut dalam pasal 2 yakni sebagai berikut:

1. Hakim harus menjalankan fungsi peradilan secara mandiri dan bebas dari pengaruh, tekanan, ancaman atau bujukan, baik yang bersifat langsung maupun tidak langsung dari pihak manapun.

2. Hakim wajib bebas dari hubungan yang tidak patut dengan lembaga eksekutif maupun legislatif serta kelompok lain yang berpotensi mengancam kemandirian 
(independensi) Hakim dan Badan Peradilan.

3. Hakim wajib berperilaku mandiri guna memperkuat kepercayaan masyarakat terhadap Badan Peradilan.

Lalu bagaimana dengan kondisi Yurisprudensi yang merupakan suatu putusan-putusan Hakim terlebih dahulu yang isinya memuat pendapat-pendapat atau pertimbangan Hakim terhadap perkara yang ia periksa, apakah pendapat ini termasuk pendapat yang dilarang oleh kode etik ini sehingga menciderai kemerdekaan Hakim atau tidak.

Untuk menjawab persoalan diatas, maka penulis menyatakan bahwa yurisprudensi tidak termasuk pendapat yang dilarang dalam aturan kode etik ini. Jika kita hubungkan dengan pembahasan pertama bahwa Yurisprudensi merupakan sumber hukum formil, maka dapat disimpulkan bahwa Hakim bebas menggunakan yurisprudensi sebagai dasar hukum apabila ia menemukan persoalan yang sama dengan isi yurisprudensi tersebut. Harus disadari betul, selama putusan Hakim tersebut telah berkekuatan hukum tetap dan Mahkamah Agung telah menilai putusan tersebut sebagai yurisprudensi, maka sifatnya berubah menjadi hukum positif yang dapat dijadikan sumber hukum umum. Sehingga tidaklah benar apabila seorang Hakim mengikuti atau menuruti suatu putusan Hakim lain dalam hal memutus perkara dimaknai sebagai penundukan terhadap putusan Hakim terdahulu. Dengan Kata lain, pemakaian Yurisprudensi dalam putusan Hakim tidak mempengaruhi prinsip kemandirian seorang Hakim sesuai dengan Kode Etik Pedoman Perilaku Hakim.

\section{Penutup}

Yurisprudensi adalah sebuah sumber hukum formil yang berlaku secara umum. Di Indonesia, hanya Mahkamah Agung lah yang berwenang untuk menentukan suatu yurisprudensi. Ketika Suatu putusan Pengadilan yang berkekuatan hukum tetap tersebut di nilai oleh Mahkamah Agung sebagai sebuah Yurisprudensi, maka sifatnya berubah menjadi hukum positif. Maka Hakim lain dapat mempergunakan yurisprudensi tersebut sebagai dasar pertimbangan dalam putusannya. Hal tersebut tentu tidak menciderai kemandirian Hakim yang tercantum dalam kode etik dalam memutuskan suatu perkara. Indepedensi Hakim tetap terjaga selama Yurisprudensi tersebut sifatnya tidak memaksa harus diterapkan dalam putusan Hakim selanjutnya sehingga konsep keterikatannya adalah persuasif. Menurut Penulis yang terpenting dipahami adalah apakah Hakim dalam membuat putusan memiliki ratio legis sehingga ia harus memakai 
Yurisprudensi tersebut, apabila ada maka hal tersebut bukanlah sebuah "pengaruh" dari Hakim lain terhadap putusan yang ia buat. Disisi lain Yurisprudensi itu akan melengkapi kekosongan hukum sehingga memudahkan Hakim lain apabila menghadapi perkara yang mirip dengan putusan Hakim terdahulu dan dapat dijadikan alat penyatuan hukum yang konkrit sehingga tidak terjadi disparitas yang sangat jauh.

Yurisprudensi adalah hal yang sangat baik dalam rangka perkembangan / penyempurnaan hukum, ditambah Mahkamah Agung melalui SEMA nomor 2 Tahun 1972 Tentang pengumpulan Yurisprudensi mengungkapkan keingingan untuk terwujudnya penyatuan hukum melalui adanya Yurisprudensi, sehingga haruslah dibuatkan peraturan yang jelas mengenai Yurisprudensi ini.

\section{Bibliografi}

\section{Buku}

Bagir Manan. 2004. Hukum Positif Indonesia Satu Kajian Teoritik. Yogyakarta: FH UII Press.

Bagir Manan dan Magnar. 1997. Beberapa Masalah Hukum Tata Negara Indonesia. Bandung: Alumni.

Badan Pembinaan Hukum Nasional (BPHN). 1992. Peningkatan Yurisprudensi Sebagai Sumber Hukum, Penelitian Hukum. Jakarta: Badan Pembinaan Hukum Nasional.
Hans Kelsen. 2006. Teori Hans Kelsen tentang Hukum. Jakarta: Konstitusi Press.

Jimly Asshidiqie. 2014. Pengantar IImu Hukum Tata Negara. Jakarta: PT. RajaGrafindo Persada.

Johannes Ibrahim dan Lindawaty Sewu. 2007. Hukum Hakim. rechterrecht.

Luhut M. P. Pangaribuan. 2009. Lay Judges \& Hakim Ad Hoc Suatu Studi Teoritis Mengenai Sistem Peradilan Pidana Indonesia. Jakarta: Kerjasama Program Pasca Sarjana Fakultas Hukum Universitas Indonesia dengan Penerbit Papas Sinar Sinanti.

Maria Farida. 2011. Ilmu Perundangundangan 1. Yogyakarta: Penerbit Kanisius.

Puslitbang Hukum dan Peradilan Badan Litbang Diklat Kumdil MA RI. 2010. Kedudukan dan Relevansi Yurisprudensi Untuk Mengurangi Disparitas Putusan Pengadilan, Laporan Penelitian. Jakarta: Penerbit Balitbang Pendidikan dan Pelatihan Hukum dan Peradilan MA RI.

Sebastiaan Pompe. 2012. Runtuhnya Institusi Mahkamah Agung. Jakarta: Lembaga Kajian dan Advokasi untuk Independensi Peradilan.

Soerjono Soekanto dan Sri Mamudji. 2001. Penelitian Hukum Normatif, Suatu Tinjauan Singkat. Jakarta: Rajawali Pers.

Teguh Satya Bhakti. 2017. Pembangunan Hukum Administrasi Negara Melalui Putusan-Putusan Peradilan Tata Usaha Negara. Jakarta: Puslitbang Hukum dan Peradilan Badan Litbang Diklat Kumdil 
Mahkamah Agung Republik Indonesia.

\section{Jurnal}

Oly Viana Agustine. 2018. "Keberlakuan

Yurisprudensi

pada

Kewenangan

Pengujian

Undang-Undang dalam Putusan

Mahkamah Konstitusi", Jurnal

Konstitusi, 15 (3): 642-665.

Zaki Ulya, 2016. "Pembatalan Kewenangan Komisi Yudisial

Dalam Rekrutmen Hakim

Dikaitkan Dengan Konsep Independensi Hakim (Studi

Putusan Mahkamah Konstitusi

Nomor 43/Puu-Xiii/2015)",

Mimbar Hukum, 28 (3): 482-496.

\section{Majalah}

Miftakhul Huda. 2010. "Yurisprudensi".

Majalah Konstitusi, April 2010.

\section{Internet}

Sabrina Asril. 2015. LelP.Ada 130 Kasus yang Diterima Kasasinya oleh

https://nasional.kompas.com/rea d/2015/02/22/17174431/readadverd.html, diakses pada hari Senin, 14 Oktober 2019. 